\title{
Bipartite Atlas with Os Odontoideum with Block Cervical Vertebrae: A Case Report with Emphasis on the "Overlooked" C1 Lateral Masses
}

\author{
Atlas Bipartita'nın Os Odontoideum ve Blok Servikal Vertebra ile \\ Birlikteliği: Olgu Sunumu ve "Gözden Kaçan" C1 Lateral Kitlelerine \\ Vurgu
}

Pravin SALUNKE ${ }^{1}$, Sushanta K. SAHOO ${ }^{1}$, Anshu MAHAJAN ${ }^{2}$

${ }_{1} P G I M E R$, Department of Neurosurgery, Chandigarh, India

${ }_{2}^{2}$ GIMER, Department of Radiodiagnosis, Chandigarh, India

Corresponding Author: Pravin SALUNKE / E-mail: drpravin_salunke@yahoo.co.uk

\begin{abstract}
Though rare, a variety of bipartite atlas has been described. However, little has been mentioned about the hypoplastic C1 lateral masses in these cases. An unusual case of bipartite atlas, with hypoplastic lateral masses, os odontoideum and block vertebrae has been described with the surgical challenges encountered. The emphasis here is to study the $\mathrm{C} 1$ lateral masses and attempting C1-2 fusion before resorting to occipito-cervical fusion. A 42-year-old lady presented with progressive spastic quadriparesis. Radiology revealed blocked C2-5 vertebrae with os odontoideum with atlanto-axial dislocation with bifid anterior arch of atlas, hypoplastic C1 lateral masses (ill formed postero-inferior part) and posterior arch. Magnetic resonance imaging showed cervicomedullary compression. Reduction was achieved by opening the C1-2 joints posteriorly. Though bilateral C1-2 lateral mass fusion was attempted, we succeeded only on one side necessitating $\mathrm{O}-\mathrm{C} 2$ fusion on the other. Patient improved neurologically, though neck movements were restricted. Partially formed (peg shaped) lateral mass of C1 suggests its development from more than one sclerotome. With normal superior facets of $\mathrm{C} 1$ lateral mass, an attempt should always be made at fusing the C1-2 joint rather than O-C2 in such cases to preserve some neck movements.
\end{abstract}

KEYWORDS: Bipartite atlas, Lateral mass, Os odontoideum, C1-2 lateral mass fusion

öz

Nadir olmakla birlikte atlas bipartita'nın bir varyasyonu tanımlanmıştır. Ancak bu tür olgularda hipoplastik C1 lateral kitleleri konusunda çok az bahsedilmiştir. Hipoplastik lateral kitle, os odontoideum ve blok vertebranın eşlik ettiği nadir bir atlas bipartita olgusu cerrahi özellikleri ile birlikte sunuldu. Burada üzerine vurgu yapılan konu, oksipitoservikal füzyondan önce C1-C2 füzyon yapılması ve C1 lateral kitlelerinin incelenmesidir. Kırk iki yaşında kadın hasta ilerleyici spastik kuadriparezi ile başvurdu. Radyolojik inceleme C2-C5 blok vertebra, os odontoideum, atlanto-aksiyel dislokasyon, atlasın anterior arkusunun bifid yapıda olması, hipoplastik C1 lateral kitleleri (özellikle posteriorinferior kısmı gelişmemiş) ve posterior arkus varlığını gösterdi. Manyetik rezonans incelemesi servikomedüller basıyı ortaya koydu. Redüksiyon C1-C2 eklemlerini posteriordan açarak sağlandı. Bilateral C1-2 lateral kitle füzyonu için girişim yapıldı. Bu sadece bir tarafta başarıldı, diğer tarafta ise Oksipit-C2 füzyonu yapıldı. Hastada nörolojik düzelme oldu ancak boyun hareketlerinde kısıtlılık oluştu. Kısmen oluşmuş olan (kanca şeklinde) C1 lateral kitle varlığı bu yapının birden fazla sklerotomdan geliştiğini düşündürmektedir. Bu tür olgularda bazı boyun hareketlerini korumak için normal süperior faset eklemi olan C1 lateral kitle varlığında her zaman öncelikle, Oksipit-C2'den çok C1-C2 eklem füzyonu yapılması için girişimde bulunulmalıdır.

ANAHTAR SÖZCÜKLER: Atlas bipartita, Lateral kitle, Os odontoideum, C1-2 lateral kitle füzyon

\section{INTRODUCTION}

The presence of os odontoideum with bipartite atlas is sparingly reported $(1,6)$. Interestingly, os odontoideum with bipartite atlas and block cervical vertebrae has never been reported. We report an unusual case of midline cleft in anterior atlas arch with aplasia of the posterior arch and peg shaped facets associated with os odontoideum and block axial and subaxial vertebrae. The difficulties encountered in atlanto-axial fusion in such a case due to hypoplastic $\mathrm{C} 1$ facets have been described.

\section{CASE REPORT}

A 42-year-old lady presented with progressive spastic quadriparesis of 3-month duration. The flexion-extension X-ray Cervical spine revealed an irreducible atlanto-axial dislocation with block C2-5 vertebra. The computed tomography (CT) of the craniovertebral junction (CVJ) clarified the presence of bifid anterior arch of atlas with aplasia of posterior arch. There was antero-posterior dislocation and telescoping of the $\mathrm{C} 2$ within $\mathrm{C} 1$ with right $\mathrm{C} 2$ facet lying medial to the $\mathrm{C} 1$ facet. Bilateral C1 facets were peg shaped with ill-formed postero- 
inferior portion. The right vertebral artery was absent (Figure $1 \mathrm{~A}-\mathrm{K})$.

She experienced partial reduction with traction. She underwent direct posterior reduction and fusion. Intraoperatively, the lamina of the axis was traced to open up bilateral C1-2 joints. The postero-superior wedge of C2 facets and the antero-inferior wedge of $\mathrm{C} 1$ facets were drilled so as to reduce the joint completely (5). Use of spacers with bone graft in C1-2 joint space reduced the vertical atlantoaxial dislocation completely and pressing the C2-3 spinous process anteriorly, antero-posterior reduction could be achieved. An attempt was made to insert $C 1$ lateral mass screws but we succeeded only on one side as we could not get good purchase due to incorrect trajectory on the other side. Additionally, the $C 1$ facet fractured partially on repeated attempts. This necessitated O-C2 fusion on one side (Figure 2A-E). Also, the lone vertebral artery posed an additional challenge to insert the screw in hypoplastic C1 facet. Unfortunately, we do not have the facility of navigation to aid proper screw placement.

Her symptoms improved postoperatively. She is independent and doing well at 5 month follow up. She does complain of restricted neck movements.

\section{DISCUSSION}

Each vertebra is formed from contribution of two adjacent sclerotomes (2). Any defect in the segmentation gives rise to block vertebrae as found in our patient.

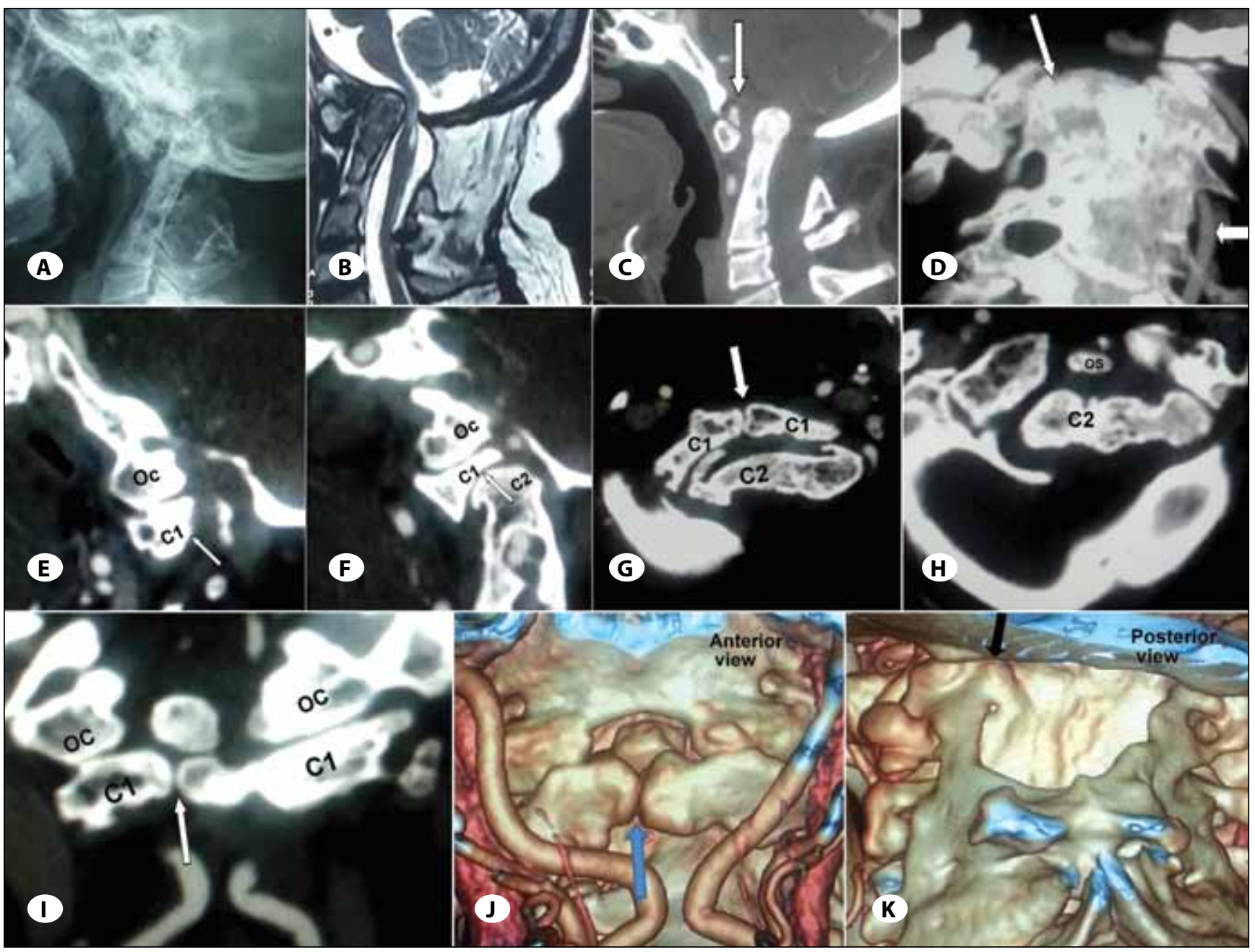

Figure 1: A) X ray cervical spine lateral view showing fused C2-5 vertebrae with vertical and antero-posterior dislocation. The posterior arch of atlas is hypoplastic. B) Sagittal MRI showing cervicomedullary compression with signal change. C, D) Mid-sagittal and coronal reconstructed CTA image showing os odontoideum (arrow) with vertical atlanto-axial dislocation. Note the right C2 facet lying medial to $\mathrm{C} 1$ lateral mass (arrow). Also note the lone left vertebral artery (arrow). E, F) Right and left parasagittal CT images showing Peg shaped C1 lateral masses (arrows showing hypoplastic medial-postero-inferior portion) and normal Occipito (Oc)-atlantal joint (C1) G, H) C1-2 axial CT images showing bifid anterior arch of C1 with C2 body seen within C1. I, J) anterior view showing bifid C1 arch (arrow) with hypoplastic lateral masses but with good superior C1 facets and atlanto-occipital joints. K) Posterior view of 3D-CT showing absent C1 posterior arch (black arrow). 


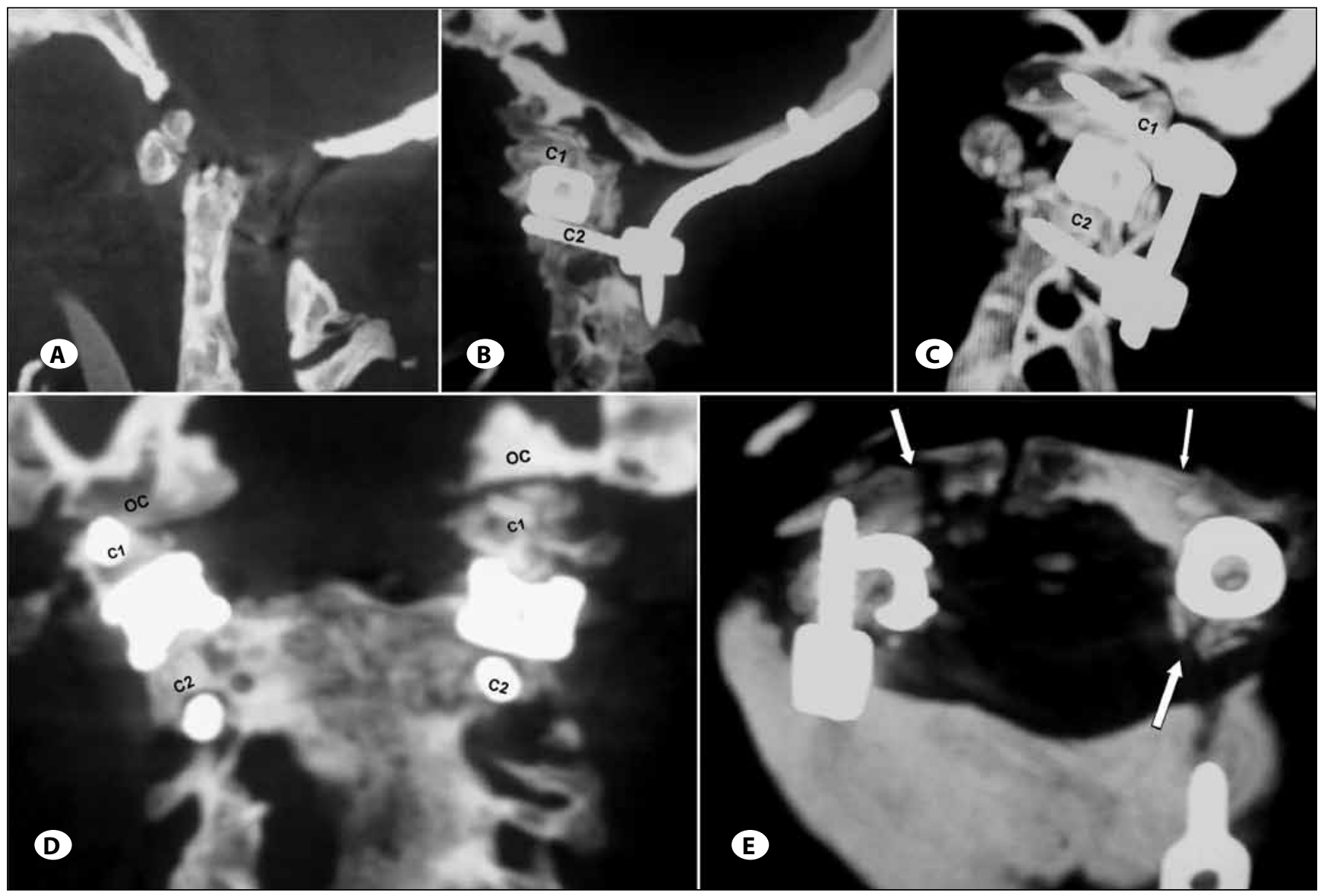

Figure 2: A) Mid sagittal CT image showing complete reduction of dislocation. B) Left parasagittal CT image showing OC2 fusion with precurved rod and pars screw with spacer in C1-2 joint C) Right parasagittal images showing C1 lateral mass and C2 pars screw with spacer and bone graft in joint space. D) Coronal CT image showing complete reduction with spacers in bilateral C1-2 joints. E) axial image through C1 showing fractured (iatrogenic) left C1 lateral mass (arrows) necessitating OC2 fusion. There is another fracture (arrow) between right lateral mass and arch of atlas. However, the lateral mass is intact providing a good purchase for the screw.

The $\mathrm{C} 1$ arch is formed by the proatlas and C1 sclerotome. The centrum of $\mathrm{C} 1$ sclerotome forms the dens and the hypocentrum forms the anterior arch of $\mathrm{C} 1$ (2). The dens may fail to fuse to the $\mathrm{C} 2$ body, giving rise to os odontoideum and is commonly associated with a hypertrophied anterior $\mathrm{C} 1 \mathrm{arch}$ (3). However, in few patients, like ours, the os odontoideum may be associated with a bifid anterior arch of atlas instead of a hypertrophic $\mathrm{C} 1$ anterior arch. Such an association is possible due to involvement of vascular supply to the entire sclerotome or genetic aberration, affecting all its components (3).

The proatlas has been thought to form the tip of dens, lateral masses of $\mathrm{C} 1$ and the superior portion of the posterior $\mathrm{C} 1$ arch (2). The $\mathrm{C} 1$ anterior arch, dens and the inferior portion of $\mathrm{C} 1$ posterior arch is possibly derived from $\mathrm{C} 1$ sclerotome (2). A variety of bipartite atlas has been described depending on the defect of $\mathrm{C} 1$ anterior arch with or without defects of posterior arch (6). Unfortunately, the lateral masses of C1 have received very little attention. The $\mathrm{C} 1$ lateral masses were peg shaped with normal antero-superior half in our case.
The absence of posterior arch with poorly formed posterior half of lateral masses suggests the role of $\mathrm{C} 1$ sclerotome in the development of both. This makes the $\mathrm{C} 1$ inferior sagittal facetal angle acute leading to progressive atlanto-axial dislocation (5). The superior facetal surface and anterosuperior portion of $\mathrm{C} 1$ lateral mass is likely to develop form the proatlas. The normal superior facet of $\mathrm{C} 1$ provides stable articulation at atlanto-occipital joint.

The poor development of $\mathrm{C} 1$ lateral mass has a bearing on the management. Though both the anterior and posterior arch of C1 may be bifid, well-developed lateral masses help in achieving a good C1-2 fusion without compromising on occipito-atlanto joint. Occipito-axial fusion is undesirable as it restricts the movement further especially with fused subaxial spine. The hypoplasia of $\mathrm{C} 1$ lateral masses (postero-inferior half) makes it difficult to fuse C1-2 especially in absence of posterior $\mathrm{C} 1 \mathrm{arch}$. Though the lateral masses of $\mathrm{C} 1$ may be hypoplastic, C1-2 joint surface should be drilled. This aids in C1-2 fusion apart from achieving reduction. Insertion of C1 lateral mass screw should be attempted with normal superior 
facets of hypoplastic C1 lateral mass before planning a direct $\mathrm{O}-\mathrm{C} 2$ fusion. The vertebral artery should be addressed appropriately (4).

Apart from rare association of os odontoideum with poorly formed C1 arches and fused C2-4 vertebrae, this report highlights the importance of studying the $\mathrm{C} 1$ lateral masses. Partially formed (peg shaped) lateral mass of $C 1$ suggests its development from more than one sclerotome. With normal superior facets of $\mathrm{C} 1$ lateral mass, an attempt should always be made at fusing the $\mathrm{C} 1-2$ joint rather than $\mathrm{O}-\mathrm{C} 2$ in such cases.

\section{REFERENCES}

1. Garg A, Gaikwad SB, Gupta V, Mishra NK, Kale SS, Singh J: Bipartite atlas with os odontoideum: Case report. Spine (Phila Pa 1976) 29(2):E35-38, 2004
2. Menezes $\mathrm{AH}$ : Craniocervical developmental anatomy and its implications. Childs Nerv Syst 24(10):1109-1122, 2008

3. Salunke P, Futane S, Khandelwal NK, Mukherjee KK: Complete segmentation failure causing non-dysjunction of os odontoideum and hypertrophic $\mathrm{C} 1$ arch: A case report. Clin Neurol Neurosurg. 115(7):1128-1130, 2013

4. Salunke P, Futane S, Sahoo SK, Ghuman MS, Khandelwal N: Operative nuances to safeguard anomalous vertebral artery without compromising the surgery for congenital atlantoaxial dislocation: Untying a tough knot between vessel and bone. J Neurosurg Spine 20(1):5-10, 2014

5. Salunke P, Sharma M, sodhi HB, Mukherjee KK, Khandelwal NK: Congenital atlantoaxial dislocation: A dynamic process and role of facets in irreducibility. J Neurosurg Spine 15(6): 678-685, 2011

6. Weng C, Wang LM, Wang WD, Tan HY: Bipartite atlas with os odontoideum and synovial cyst: Case report and review literature. Spine (Phila Pa 1976) 35(12):E568-575, 2010 